\title{
Prospek Pengembangan Pembenihan Ikan Lele (Clarias sp.) di Desa Babakan Kecamatan Ciseeng Kabupaten Bogor
}

\author{
Catfish (Clarias sp.) Hatchery Development Prospects in Babakan Village, Ciseeng, Bogor
}

\author{
Asep Korlan Dedi ${ }^{*}$, Ani Suryani ${ }^{\sharp}$, dan Eko Ruddy Cahyadi ${ }^{3 *}$
}

${ }^{1}$ Kementerian Kelautan dan Perikanan

Gd. Mina Bahari I Jl. Medan Merdeka Timur No. 16, Jakarta Pusat 10110

${ }^{2}$ Departemen Teknologi Industri Pertanian, Fakultas Teknologi Pertanian, Institut Pertanian Bogor

${ }^{3}$ Departemen Manajemen, Fakultas Ekonomi dan Manajemen, Institut Pertanian Bogor

\#Jl. Kamper, Kampus IPB Dramaga, Bogor 16680

\begin{abstract}
ABSTRAK
Dalam lima tahun terakhir kebutuhan benih ikan lele yang selalu meningkat, belum mampu dipenuhi oleh produksi yang ada. Tujuan penelitian ini: (1) Mendapatkan informasi kelayakan usaha pembenihan ikan lele di Desa Babakan, (2) Mengidentifikasi faktor-faktor internal dan eksternal yang berpengaruh terhadap pengembangan pembenihan ikan lele di Desa Babakan dan (3) Merumuskan strategi alternatif pengembangan pembenihan ikan lele di Desa Babakan. Kriteria analisis kelayakan yang digunakan adalah Net Present Value (NPV), Net Benefit Cost Ratio (Net B/C), Internal Rate of Return (IRR), Break Even Point (BEP) dan Payback Period (PBP). Selanjutnya metode untuk mengidentifikasi faktor-faktor yang berpengaruh terhadap pengembangan usaha menggunakan matriks Internal Factor Evaluation (IFE), matriks External Factor Evaluation (EFE), matriks Internal External (IE) dan matriks Strengths, Weaknesses, Opportunities, and Threats (SWOT), sehingga pada tahap terakhir menghasilkan strategi alternatif pengembangan menggunakan Quantitative Strategic Planning Matrix (QSPM). Kajian ini menunjukkan usaha pembenihan ikan lele di Desa Babakan masih lemah pada seluruh aspek non finansial. Analisis kelayakan finansial terhadap pembenih di Desa Babakan, menghasilkan layak 100\%. Seluruh nilai NPV yang diperoleh lebih besar dari nol, yaitu diantara Rp3.395.841-Rp53.262.759. Seluruh nilai IRR yang diperoleh lebih besar dari suku bunga (14\%), yaitu $28,31 \%$ dan $45,25 \%$. Seluruh nilai Net B/C yang diperoleh lebih besar dari 1, yaitu 1,30 dan 1,62. Seluruh nilai PBP yang diperoleh lebih kecil dari tiga tahun, yaitu diantara 1,8 tahun dan 2,3 tahun. Berdasarkan hasil analisis IE maupun SWOT, usaha pembenihan ikan lele ini perlu melakukan strategi progresif. Alternatif strategi pengembangan usaha terbaik dari analisis QSPM adalah penerapan Cara Pembenihan Ikan yang Baik (CPIB) meningkatkan produktivitas dan mutu benih, sehingga program minapolitan tercapai.
\end{abstract}

Kata kunci: kelayakan usaha, pembenihan ikan Lele, strategi pengembangan

\section{ABSTRACT}

In the last five years the seed needs catfish are always increasing, yet able to be met by existing production. The objectives of research are as follows: (1) To obtain information on the feasibility business of catfish hatchery in Babakan village, (2) To identify internal and external factors that influence toward catfish hatchery development in Babakan and (3) To provide the alternative strategy for catfish hatchery development in Babakan. The criteria of the business feasibility analysis used in this study are Net Present Value (NPV), Net Benefit Cost Ratio (Net B/C), Internal Rate of Return (IRR), Break Even Point (BEP), and Payback Period (PBP). While the factors that influence toward business development are identified using Internal Factor Evaluation (IFE) matrix, External Factor Evaluation (EFE) matrix, Internal External (IE) matrix, and Strengths, Weaknesses, Opportunities, and Threats (SWOT) matrix. Lastly the Quantitative Strategic Planning Matrix (QSPM) is applied to provide an alternative strategy of business

\footnotetext{
*) Korespondensi:

Gd. Mina Bahari III 1t. 9 Jl.Medan Merdeka Timur No. 16, Jakarta 10110
} 
development. The results of the non-financial feasibility analysis showed that the catfish hatchery business in Babakan is still weak on the whole non-financial aspects. Based on the results of a financial feasibility analysis with the feasibility criteria and assumptions which have been determined, it is known that the catfish hatchery business of 7 fish farmers is feasible with $100 \%$. The entire value of the NPV is greater than zero between International Drawing Right (IDR) 3.395.841 and IDR 53.262.759. The entire value of IRR is greater than the interest rate (14\%) between $28,31 \%$ and $45,25 \%$. The entire value of Net $\mathrm{B} / \mathrm{C}$ is greater than 1 between 1.30 and 1.62. The entire value of the PBP is less than 3 years between 1.8 years and 2.3 years. Based on the result of both IE and SWOT analysis, of 7 fish farmers in Babakan that the catfish hatchery need to defend, develop and undertake progressive strategies. The best alternative strategy of business development business that recommended from QSPM analysis is the application of Good Hatchery Practices (CPIB) to increase production and quality of seeds, so that minapolitan program is reachable.

Key words: feasibility, hatchery catfish, strategy development

\section{PENDAHULUAN}

Ikan lele (Clarias sp.) merupakan salah satu jenis ikan air tawar yang cukup digemari masyarakat Indonesia, selain harga yang relatif murah, mudah dibudidayakan dan memiliki kandungan gizi yang tinggi. Kebutuhan ikan lele di Indonesia setiap tahunnya selalu meningkat. Hal ini sebagai gambaran bahwa pertumbuhan Industri Kecil Menengah (IKM) dalam pemanfaatan ikan lele semakin berkembang, sehingga mampu menumbuhkan wirausahawan-wirausahawan baru bidang perikanan. Dahulu ikan lele dipandang ikan murahan dan hanya dikonsumsi oleh keluarga petani, sekarang ikan lele merupakan komoditas yang sangat disukai oleh masyarakat (Sukardono et al, 2013). Selain itu rasa daging yang khas, serta cara memasak dan menghidangkan secara tradisional, menjadikan menu sajian ikan lele digemari masyarakat luas (Jaja et al, 2013). Para wirausahawan adalah pendorong perubahan, inovasi dan kemajuan suatu negara (Adelina, 2011).

Konsumsi ikan lele masih didominasi wilayah Jawa 250 ton per hari. Selain Jakarta, konsumsi lele terbanyak berada di Yogyakarta (KKP, 2012). Beberapa wilayah yang ada di Kabupaten Bogor merupakan sentra produksi lele, diantaranya Ciseeng, Parung, Gunung Sindur dan Gadog. Kabupaten Bogor mempunyai lokasi berdekatan dengan pusat pasar domestik, yaitu kawasan Jabodetabek dengan kebutuhan pasokan lele 150 ton per hari (Ditjen P2HP, 2010), sedangkan kebutuhan lele di Bogor sudah menembus 30 ton per hari (Wibowo, 2011).

Dalam rangka peningkatan produksi perikanan budidaya 353\% (KKP, 2011), peranan bidang pembenihan menjadi sangat penting untuk menghasilkan benih bermutu baik dan produksi yang tinggi dalam memenuhi kebutuhan benih untuk pembesaran.

Ketersediaan benih lele di Kabupaten Bogor pada dua tahun terakhir (2011-2012) 54.684.000 ekor $(5,25 \%$ dari ketersediaan benih lele di Provinsi Jawa Barat) dan 175.582 .800 ekor $(1,89 \%$ dari ketersediaan benih lele di Provinsi Jawa Barat) (Buku Data Perikanan, Dinas Peternakan dan Perikanan Kabupaten Bogor 2010, 2012). Hasil produksi benih lele secara Nasional mengalami peningkatan terutama pada tahun 2011. Di tingkat Provinsi Jawa Barat produksi benih lele berfluktuasi, meningkat pada tahun 2011 dan menurun pada tahun 2012. Banyak hasil samping dari produksi ikan lele yang dapat dimanfaatkan, seperti hasil penelitian Ferazuma, Marliyati dan Amalia (2011), dalam hal ini kepala ikan lele dumbo yang kaya kalsium dapat diolah menjadi tepung dan diaplikasikan pada pembuatan produk crackers. Menurut Mervina, Kusharto dan Merliyati (2012), ikan Lele dapat dibuat menjadi tepung, sebagai bahan substitusi tepung ikan lele dan isolat protein kedelai untuk membuat biscuit yang berprotein tinggi.

Kekurangan pasokan benih lele berkaitan erat dengan kegiatan usaha pembesaran yang semakin meningkat. Dalam rangka memenuhi kebutuhan pasar domestik, kegiatan pembenihan perlu dilakukan perbaikan pada aspek teknis dan non teknis. Dengan perbaikan pada kedua aspek tersebut diharapkan peningkatkan mutu dan produktivitas benih dapat tercapai, baik di tingkat Kabupaten maupun secara Nasional.

Bentuk dukungan Pemerintah Pusat melalui Kementerian Kelautan dan Perikanan (KKP) dalam meningkatkan produktifitas usaha budidaya ikan lele dengan Program Minapolitan. Bogor merupakan salah satu yang ditetapkan menjadi kawasan minapolitan dengan komoditi 
unggulan ikan lele. Bentuk dukungan Pemerintah Provinsi Jawa Barat berupa Anggaran Pendapatan Belanja Daerah (APBD) Jawa Barat yang menganggarkan bantuan terhadap kelompok budidaya perikanan. Dukungan Pemerintah Daerah Kabupaten Bogor berupa penetapan lokasi kawasan minapolitan.

Pemerintah melalui Ditjen Perikanan Budidaya saat ini sedang melakukan sertifikasi Cara Pembenihan Ikan yang Baik (CPIB). Sertifikasi CPIB dilakukan kepada Unit Pembenih Rakyat (UPR) dan usaha pembenihan di seluruh Indonesia. Kegiatan tersebut penting dilakukan, agar produktivitas meningkat dan menghasilkan mutu yang baik. Mutu benih merupakan salah satu faktor penentu keberhasilan usaha budidaya. Penggunaan mutu benih lele yang baik dapat menurunkan kegagalan dan risiko usaha, meningkatkan produktivitas usaha dan pada akhirnya diharapkan mampu meningkatkan pendapatan para pembenih lele.

Desa Babakan, Kecamatan Ciseeng, Kabupaten Bogor merupakan kawasan potensial pembenihan ikan lele, kegiatan pembenihan ikan lele sudah cukup lama dilakukan dan merupakan salah satu sentra produksi pembenihan ikan lele di Kabupaten Bogor. Berdasarkan data di atas, diperlukan kegiatan penelitian pada usaha pembenihan ikan lele, untuk melihat potensi, aspek pendukung, aspek penghambat dan pola usaha yang dilakukan.

Tujuan penelitian ini: (1) Mendapatkan informasi tentang kelayakan usaha pembenihan ikan lele, (2) Mengidentifikasi faktor-faktor internal dan eksternal yang berpengaruh terhadap pengembangan pembenihan ikan lele, (3) Merumuskan strategi alternatif pengembangan pembenihan ikan Lele di Desa Babakan, Kecamatan Ciseeng, Kabupaten Bogor.

\section{METODE PENELITIAN}

Penelitian dilaksanakan di Desa Babakan menggunakan data primer dan sekunder, baik kualitatif maupun kuantitatif. Metode pengumpulan data dilakukan dengan cara berikut:

a. Data Primer

Data Primer dikumpulkan menggunakan metode purposive sampling dengan jenis quota sampling. Responden adalah pemilik usaha pembenihan di Desa Babakan, Ciseeng, Bogor dengan jumlah 7 orang. Metode pengumpulan data primer dengan cara wawancara langsung. b. Data Sekunder

Diambil dari literatur buku, jurnal dan data Petugas Penyuluh Lapangan bidang Perikanan Kecamatan Ciseeng, Kabupaten Bogor.

c. Observasi

Langkah-langkah dalam analisis data dapat diuraikan sebagai berikut:

1. Pengolahan data dilakukan untuk menganalisa kelayakan usaha secara kuantitatif dan kualitatif. Analisis kualitatif diterapkan pada aspek non finansial, sedangkan analisis kuantitatif diterapkan pada aspek finansial seperti Net Present Value (NPV), Net Benefit Cost Ratio (Net B/C), Internal Rate Return (IRR), Break Even Point (BEP) dan Payback Period (PBP).

2. Proses perumusan alternatif strategi melalui tiga tahap yaitu:

a. Tahap pengumpulan data (Tahap masukan) Tahap ini adalah menetapkan visi, misi dan tujuan organisasi, selanjutnya dilakukan identifikasi data internal dan eksternal usaha pembenihan. Data yang teridentifikasi dalam pengamatan lapangan, dirangkum dalam suatu matriks, yaitu Matriks EFE digunakan untuk mengetahui peluang terbesar dan terkecil yang dimiliki usaha pembenihan dan ancaman terbesar maupun ancaman yang tidak memengaruhi usaha pembenihan, sedangkan matriks IFE digunakan untuk mengetahui kekuatan paling besar dan terkecil yang dimiliki maupun kelemahan terbesar dan terkecil yang dimiliki usaha pembenihan.

b. Tahap analisis (Tahap pencocokan)

Tahap ini memanfaatkan semua informasi kuantitatif yang sudah diperoleh pada tahap sebelumnya untuk menganalisis perumusan strategi. Analisis yang dapat digunakan sebagai alat analisis adalah matriks IE (Internal External) dan matriks SWOT (Strength, Weaknesses, Opportunities and Threats).

c. Tahap pengambilan keputusan (Tahap keputusan)

Analisis yang dapat digunakan pada tahap akhir ini adalah Quantitative Strategic Planning Matrix (QSPM). Setelah berhasil mengembangkan sejumlah alternatif strategi, usaha pembenihan harus mampu mengevaluasi dan kemudian memilih strategi terbaik, yang paling cocok dengan kondisi internal usaha pembenihan dan lingkungan eksternal. 


\section{HASIL DAN PEMBAHASAN}

Desa Babakan yang berada di Kecamatan Ciseeng Kabupaten Bogor memiliki potensi Sumber Daya Alam (SDA) yang cukup potensial untuk pengembangan usaha budidaya perikanan. Lokasi pembenihan memiliki topografi sebagian datar dan sedikit bergelombang dengan kemiringan 5-8\%, ketinggian tempat $125 \mathrm{~m}$ dari permukaan laut (dpl). Curah hujan selama lima tahun terakhir rataan $296,9 \mathrm{~mm} /$ tahun, dimana curah hujan tertinggi terjadi pada bulan Januari dan terendah pada bulan September. Kondisi demikian sesuai dengan persyaratan pengembangan budi daya lele. Jenis tanah termasuk ke dalam tanah latosal coklat kemerahan, $\mathrm{pH}$ tanah pada lahan sawah 5-6,5 dan lahan darat 5-6. Dengan jumlah penduduk Desa Babakan 14.074 orang, dengan $\pm 70 \%$ bermata pencaharian bidang perikanan. Desa Babakan memiliki potensi wilayah perikanan seluas $131 \mathrm{Ha}$, dengan jumlah petani pembenih 875 orang, yang diantaranya merupakan 173 petani pembenih lele.

Pembenihan ikan lele di Desa Babakan sudah berjalan sejak tahun 1990-an dilakukan secara otodidak dengan wadah kolam tanah. Sejalan perkembangan teknologi petani mulai mengenal pemijahan dilakukan dikolam terpal. Pemijahan dilakukan dengan beberapa metode, mulai menggunakan kelenjar hypopisa dari ikan donor untuk merangsang pemijahan, penggunaan Ovaprim dan menggunakan pemijahan secara alami. Induk lele yang digunakan adalah induk lele Dumbo, Sangkuriang dan Phyton. Umumnya pembenih menggunakan induk lele dumbo, dengan asumsi harga benih yang dihasilkan sama.

Pembenih ikan lele di Desa Babakan masih menggunakan metode seadanya, yaitu berasumsi dengan menggunakan metode yang selama ini digunakan sudah menguntungkan, padahal kegiatan usaha pembenihannya masih bisa dioptimalkan, baik mengoptimalkan lahan maupun teknik pemijahan. Rendahnya pemahaman pembenih dalam melakukan kegiatan usaha pembenihan yang sesuai aturan mengakibatkan fekunditas telur yang dihasilkan dari pemijahan masih rendah dan mortalitas setiap tingkat antara umur 10 hari ke pendederan I dan pendederan II masih cukup tinggi.

Petugas Penyuluh Lapangan (PPL) Perikanan memiliki peran penting dalam mendongkrak peningkatan produksi melalui sosialisasi dan pelatihan, serta pendekatan ke kelompok pembenih. Adanya PPL Perikanan dan petugas pendampingan diharapkan dapat membantu memecahkan kesulitan-kesulitan dalam kegiatan usaha pembenihan lele, sehingga pada akhirnya pembenih berkeinginan menerapkan inovasi teknologi pembenihan sesuai anjuran.

\section{Analisis Kelayakan Non Finansial}

Usaha pembenihan ikan lele di Desa Babakan dilihat dari sisi kelayakan non finansial mencakup beberapa aspek, yaitu teknis, pasar, manajemen, hukum, sosial ekonomi dan dampak lingkungan dapat dilihat pada Tabel 1.

\section{Analisis Kelayakan Finansial}

Analisis kelayakan usaha pembenihan ikan lele dilakukan pada 7 pembenih di Desa Babakan. Usaha pembenihan di penelitian ini dibagi ke dalam dua jenis, yaitu pendederan I sebanyak 4 pembenih dan pendederan II sebanyak 3 pembenih. Untuk melakukan analisa kelayakan usaha diperlukan adanya beberapa asumsi mengenai parameter teknologi proses maupun biaya, sebagaimana terangkum dalam Tabel 2. Asumsi ini diperoleh berdasarkan kajian terhadap usaha pembenihan ikan Lele pada UPR di Desa Babakan dan informasi yang diperoleh dari pustaka.

\section{Arus Masuk}

Berdasarkan kapasitas kolam dan produksi telur induk ikan lele masing-masing pembenih, maka arus masuk usaha pembenihan berdasarkan jenis pendederan ditampilkan pada Tabel 3. Arus masuk rataan pendederan II (Rp111.550.000) lebih besar dari pendederan I (Rp28.275.000).

\section{Arus Keluar}

Komponen biaya dalam analisis kelayakan usaha pembenihan ikan lele dibedakan menjadi dua, yaitu biaya investasi dan biaya operasional. Biaya investasi adalah komponen biaya yang diperlukan untuk memenuhi kebutuhan dana awal pendirian usaha yang meliputi lahan usaha, peralatan dan sarana produksi. biaya operasional adalah seluruh biaya yang harus dikeluarkan dalam proses produksi.

\section{Biaya Investasi}

Untuk memulai usaha pembenihan ikan lele ini, tahap awal adalah pengadaan kolam sebagai media hidup ikan. Dalam satu unit usaha, dibutuhkan kolam yang terdiri dari kolam induk lele, kolam pemijahan, kolam perawatan benih, kolam pendederan I dan kolam pendederan II. 
Biaya investasi yang dibutuhkan pada tahap awal kegiatan usaha pembenihan ikan lele ini meliputi bangunan, serta prasarana dan peralatan produksi. Komponen terbesar adalah pembuatan kolam. Biaya investasi untuk komponen lainnya relatif kecil dibandingkan biaya investasi untuk kolam.

\section{Biaya Operasional}

Biaya operasional dalam usaha pembenihan ikan lele dibedakan menjadi dua jenis biaya, yaitu biaya variabel dan biaya tetap. Pada pendederan I dan pendederan II rataan memerlukan biaya produksi/ekor berturut-turut Rp50,54 dan Rp152,33.

Tabel 1. Matriks analisis non finansial

\begin{tabular}{|c|c|c|c|c|}
\hline Aspek & Kekuatan & Kelemahan & Peluang & Ancaman \\
\hline Teknis & $\begin{array}{l}\text { 1. Air tersedia, mengandal- } \\
\text { kan saluran irigasi yang } \\
\text { bersumber dari sungai } \\
\text { Cibeuteung } \\
\text { 2. Tenaga kerja berpengala- } \\
\text { man, sebagian besar } \\
\text { masyarakat Desa Baba- } \\
\text { kan sudah lama berke- } \\
\text { cimpung dalam kegiatan } \\
\text { usaha pembenihan } \\
\text { 3. Lahan tersedia } \\
\text { 4. Pakan alami tersedia }\end{array}$ & $\begin{array}{l}\text { CPIB belum } \\
\text { dilaksanakan } \\
\text { dengan baik }\end{array}$ & & $\begin{array}{l}\text { 1. Hama dan } \\
\text { penyakit } \\
\text { 2. Cuaca } \\
\text { 3. Harga pakan } \\
\text { naik terus }\end{array}$ \\
\hline Pasar & $\begin{array}{l}\text { 1. Pasar terjamin, karena } \\
\text { letak strategik dan lokasi } \\
\text { dekat dengan unit } \\
\text { pembesaran ikan lele } \\
\text { 2. Permintaan benih tinggi, } \\
\text { sehingga permintaan } \\
\text { kebutuhan benih belum } \\
\text { dapat terpenuhi }\end{array}$ & $\begin{array}{l}\text { Harga benih tidak } \\
\text { kompetitif }\end{array}$ & & Saingan usaha \\
\hline Manajemen & & $\begin{array}{l}\text { Manajemen usaha } \\
\text { tidak tertata }\end{array}$ & $\begin{array}{l}\text { Keberadaan tenaga pe- } \\
\text { nyuluh perikanan, terkait } \\
\text { pengelolaan, pembukuan } \\
\text { dan pencatatan usaha } \\
\text { pembenihan ikan lele }\end{array}$ & \\
\hline Hukum & & $\begin{array}{l}\text { Secara umum pem- } \\
\text { benih belum mempu- } \\
\text { nyai perizinan untuk } \\
\text { usaha pembenihan } \\
\text { ikan lele }\end{array}$ & & \\
\hline Sosial ekonomi & & & $\begin{array}{l}\text { 1. Kawasan Minapolitan } \\
\text { 2. Keberadaan dan pe- } \\
\text { ngembangan usaha ikan } \\
\text { lele akan berdampak } \\
\text { positif bagi wilayah } \\
\text { sekitarnya: (a) peluang } \\
\text { kerja semakin terbuka; } \\
\text { (b) peningkatan } \\
\text { pendapatan masyarakat }\end{array}$ & \\
\hline $\begin{array}{l}\text { Dampak } \\
\text { lingkungan }\end{array}$ & & $\begin{array}{l}\text { Masih mengguna- } \\
\text { kan potas dan pakan } \\
\text { ayam mati }\end{array}$ & $\begin{array}{l}\text { Keberadaan tenaga pe- } \\
\text { nyuluh perikanan, terkait } \\
\text { dengan obat dan pakan } \\
\text { yang teregistrasi KKP }\end{array}$ & \\
\hline
\end{tabular}




\section{Analisis Laba Rugi Usaha}

Berdasarkan biaya produksi/ekor dan rataan harga jual/ekor, menghasilkan rataan keuntungan/ekor pada pendederan I dan pendederan II berturut-turut Rp16,21 dan Rp101. Beberapa pembenih (3 pembenih) menghasilkan keuntungan/ekor mencapai lebih dari 50\%.

Selama kurun waktu tiga tahun kegiatan usaha pembenihan ikan lele secara rataan akan menghasilkan keuntungan bersih per tahun Rp14.227.588 dan profit margin rataan 17,99\%. Dengan membandingkan pengeluaran untuk biaya tetap terhadap biaya variabel dan total penerimaan, maka BEP usaha rataan ini terjadi pada penjualan senilai Rp32.645.162.

Tabel 2. Asumsi untuk analisis keuangan usaha pembenihan ikan lele di Desa Babakan, Kecamatan Ciseeng, Kabupaten Bogor

\begin{tabular}{|c|c|c|c|}
\hline No. & Asumsi & Satuan & $\begin{array}{l}\text { Nilai / } \\
\text { Jumlah }\end{array}$ \\
\hline 1 & Bulan kerja/tahun & bulan & 10 \\
\hline 2 & Periode pembenihan & tahun & 3 \\
\hline \multirow[t]{3}{*}{3} & Siklus pembenihan per tahun & & \\
\hline & a. Pendederan I & siklus & 10 \\
\hline & b. Pendederan II & siklus & 6 \\
\hline \multirow[t]{3}{*}{4} & Lama menunggu pendapatan & & \\
\hline & a. Pendederan I & hari & 45 \\
\hline & b. Pendederan II & hari & 60 \\
\hline 5 & Suku Bunga per Tahun & $\%$ & 14 \\
\hline \multirow[t]{3}{*}{6} & Proporsi Modal: & & \\
\hline & a. Kredit & $\%$ & 0 \\
\hline & b. Modal sendiri & $\%$ & 100 \\
\hline
\end{tabular}

Tabel 3. Arus masuk usaha pembenihan ikan lele di Desa Babakan, Kecamatan Ciseeng, Kabupaten Bogor

\begin{tabular}{cccc}
\hline \multirow{2}{*}{ Jenis } & \multicolumn{3}{c}{ Penjualan/Tahun (Rp.) } \\
\cline { 2 - 4 } PD & Rata-Rata & Maksimum & Minimum \\
\hline PD I & 28.275 .000 & 39.250 .000 & 11.145 .739 \\
PD II & 111.550 .000 & 154.500 .000 & 39.344 .726 \\
\hline
\end{tabular}

Ket: $\mathrm{PD}$ I = pendederan I, PD II = pendederan II

\section{Analisis Kelayakan Finansial dan Kriteria Kelayakan}

Untuk aliran kas (cash flow) dalam perhitungan ini dibagi dalam dua aliran, yaitu arus masuk (cash inflow) dan arus keluar (cash outflow). Arus masuk diperoleh dari penjualan benih ikan lele selama satu tahun. Untuk arus keluar meliputi biaya investasi, biaya variabel, biaya tetap, termasuk angsuran pokok, angsuran bunga. dan pajak penghasilan.
Tabel 4. Parameter kelayakan usaha pembenihan ikan lele di Desa Babakan, Kecamatan Ciseeng, Kabupaten Bogor

\begin{tabular}{llll}
\hline No. & Kriteria & $\begin{array}{c}\text { Parameter } \\
\text { Kelayakan }\end{array}$ & $\begin{array}{c}\text { Hasil Analisis } \\
\text { Kelayakan Usaha } \\
\text { Pembenihan }\end{array}$ \\
\hline 1. & NPV $(14 \%)$ & $>0$ & \\
2. & IRR & $>14 \%$ & dapat dilihat \\
3. & Net $\mathrm{B} / \mathrm{C}$ & $>1,00$ & pada Tabel 5 \\
4. & PBP & $<3$ Tahun & \\
\hline
\end{tabular}

Evaluasi kelayakan usaha pembenihan dilakukan dengan menilai kriteria kelayakan usaha, yaitu meliputi NPV, IRR, Net B/C dan PBP. Analisis kelayakan usaha dilakukan pada 7 pembenih di Desa Babakan. Seluruh nilai NPV yang diperoleh lebih besar dari nol, yaitu diantara Rp3.395.841-Rp53.262.759. Seluruh nilai IRR yang diperoleh lebih besar dari suku bunga (14\%), yaitu $28,31 \%$ dan $45,25 \%$. Seluruh nilai Net B/C yang diperoleh lebih besar dari 1, yaitu 1,30 dan 1,62. Seluruh nilai PBP yang diperoleh lebih kecil dari tiga tahun, yaitu diantara 1,8 tahun dan 2,3 tahun. Berdasarkan analisis kelayakan usaha dengan asumsi pada Tabel 2 dan parameter kelayakan pada Tabel 4, menunjukkan bahwa usaha pembenihan ikan Lele ini layak 100\%. Oleh karena itu, dapat disimpulkan bahwa usaha pembenihan ikan lele di Desa Babakan sudah baik dan layak untuk dilakukan. Hal ini sesuai dengan penelitian yang telah dilakukan Yulinda (2012) dan Jaja et al (2013).

Tabel 5. Analsis kelayakan usaha

\begin{tabular}{lrcccc}
\hline $\begin{array}{l}\text { Pem- } \\
\text { benih }\end{array}$ & $\begin{array}{c}\text { NPV } \\
(\mathrm{Rp})\end{array}$ & $\begin{array}{c}\text { IRR } \\
(\%)\end{array}$ & $\begin{array}{c}\text { Net } \\
\text { B/C }\end{array}$ & PBP & Ket \\
\hline P 1 & 53.262 .759 & 31,43 & 1,35 & 2,2 & \\
P 2* & 3.516 .763 & 43,61 & 1,60 & 1,9 & \\
P 3* & 3.691 .565 & 34,31 & 1,34 & 2,2 & \\
P 4 & 43.273 .663 & 43,61 & 1,62 & 1,8 & Layak \\
P 5 & 22.897 .722 & 44,64 & 1,62 & 1,9 & \\
P 6 & 3.395 .841 & 28,31 & 1,30 & 2,3 & \\
P 7* & 6.337 .092 & 45,25 & 1,59 & 1,9 & \\
\hline Ket: Notasi (*) berarti pembenih pada pendederan I, & \\
\multicolumn{5}{c}{ selain itu pendederan II }
\end{tabular}

\section{Analisis Sensitivitas Kelayakan Usaha}

Sensitivitas kenaikan biaya variabel dimungkinkan dengan melihat perkembangan ekonomi saat ini dan kenaikan harga Bahan Bakar Minyak (BBM), sehingga memunculkan asumsi peningkatan biaya pakan, sedangkan pendapatan 
dianggap tetap. Analisis sensitivitas dari 7 pembenih di Desa Babakan berdasarkan kenaikan harga pakan $10 \%$ dengan asumsi pendapatan tetap. Seluruh nilai NPV yang diperoleh lebih besar dari nol, yaitu diantara Rp786.739 dan Rp43.908.903. Seluruh nilai IRR yang diperoleh lebih besar dari suku bunga (14\%), yaitu 18,50\% dan 38,93\%. Seluruh nilai Net B/C yang diperoleh lebih besar dari 1, yaitu 1,07 dan 1,52. Seluruh nilai PBP yang diperoleh lebih kecil dari tiga tahun, yaitu 2,0 tahun dan 2,8 tahun. Dengan demikian dapat disimpulkan bahwa pada suku bunga $14 \%$ dengan kenaikan harga pakan $10 \%$, usaha pembenihan ini layak dilaksanakan.

Analisis sensitivitas dari 7 pembenih di Desa Babakan berdasarkan kenaikan harga pakan $\mathbf{2 0 \%}$ dengan asumsi pendapatan tetap. Tidak seluruh nilai NPV yang diperoleh lebih besar dari nol, yaitu diantara Rp2.118.087 dan Rp34.555.048. Tidak seluruh nilai IRR yang diperoleh lebih besar dari suku bunga (14\%), yaitu 1,20\% dan 33,57\%. Tidak seluruh nilai Net B/C yang diperoleh lebih besar dari 1, yaitu 0,80 dan 1,41. Tidak seluruh nilai PBP yang diperoleh lebih kecil dari tiga tahun, yaitu 2,1 tahun dan 3,7 tahun. Dengan demikian dapat disimpulkan bahwa pada suku bunga $14 \%$, dengan kenaikan harga pakan $20 \%$, terdapat 3 usaha pembenihan pada pendederan I yang tidak layak dilaksanakan. Hal tersebut terjadi karena usaha pembenihan pada pendederan I lebih mengandalkan pakan alami yang pada umumnya diperoleh langsung dari alami sehingga tidak memerlukan biaya tambahan.

\section{Strategi Pengembangan Usaha}

Hasil identifikasi kekuatan, kelemahan, peluang dan ancaman terhadap pembenih ikan lele di Desa Babakan dalam menjalankan usaha pembenihan ikan lele sebagai berikut:

1. Kekuatan, meliputi air tersedia sepanjang tahun, tenaga kerja tersedia, lahan untuk pengembangan tersedia, pakan alami untuk induk tersedia, dan pakan alami benih tersedia (cacing sutra+kutu air).

2. Kelemahan, meliputi harga dibanding benih dari luar lebih tinggi, manajemen usaha tidak tertata, modal kurang, produksi dilakukan belum sesuai anjuran CPIB, dan kurang inovasi.

3. Peluang, meliputi pasar pasti/tersedia, permintaan benih tinggi, tenaga penyuluh perikanan ada, investor, dan perupakan kawasan minapolitan.
4. Ancaman, meliputi saingan usaha pembenihan dari luar daerah, hama (sidat, kodok, ucrit), penyakit (ikan kembung) sulit diobati, cuaca (hujan terus menerus), dan harga pakan naik terus.

\section{Analisis Matriks IFE}

Setelah diperoleh faktor-faktor internal usaha pembenihan ikan lele yang meliputi kekuatan dan kelemahan, maka dilakukan pemberian kuesioner mengenai pemberian peringkat (rating) terhadap faktor-faktor kekuatan dan kelemahan selanjutnya melakukan pembobotan. Setelah diperoleh hasil peringkat dan pembobotan oleh para responden, maka tahapan selanjutnya yakni mencari nilai rata-rata peringkat dan pembobotan dari masing-masing faktor tersebut. Dilanjutkan dengan mencari nilai bobot dan skor terbobot dari masing-masing faktor. Tabel 6 merupakan hasil analisis matriks IFE pada usaha pembenihan ikan lele di Desa Babakan.

Tabel 6. Matriks IFE gabungan usaha pembenihan ikan lele di Desa Babakan, Kecamatan Ciseeng, Kabupaten Bogor

\begin{tabular}{|c|c|c|c|c|}
\hline \multirow{2}{*}{\multicolumn{2}{|c|}{ Faktor Internal }} & \multirow{2}{*}{$\frac{\text { Bobot }}{\text { (a) }}$} & Rating & $\begin{array}{c}\text { Skor } \\
\text { Terbobot }\end{array}$ \\
\hline & & & (b) & $(a \times b)$ \\
\hline \multicolumn{5}{|c|}{ Kekuatan: } \\
\hline 1. & $\begin{array}{l}\text { Air tersedia } \\
\text { sepanjang tahun }\end{array}$ & 0,141 & 3,714 & 0,522 \\
\hline 2. & Tenaga kerja tersedia & 0,078 & 3,000 & 0,234 \\
\hline 3. & $\begin{array}{l}\text { Lahan untuk pengem. } \\
\text { bangan tersedia }\end{array}$ & 0,117 & 3,286 & 0,385 \\
\hline 4. & $\begin{array}{l}\text { Pakan alami untuk } \\
\text { induk tersedia }\end{array}$ & 0,133 & 3,429 & 0,455 \\
\hline 5. & $\begin{array}{l}\text { Pakan alami benih } \\
\text { tersedia (cacing } \\
\text { sutra+kutu air) }\end{array}$ & 0,125 & 3,286 & 0,411 \\
\hline \multicolumn{5}{|c|}{ Kelemahan: } \\
\hline 1. & $\begin{array}{l}\text { Harga dibanding } \\
\text { benih dari luar lebih } \\
\text { tinggi }\end{array}$ & 0,109 & 1,714 & 0,188 \\
\hline 2. & $\begin{array}{l}\text { Manajemen usaha } \\
\text { tidak tertata }\end{array}$ & 0,102 & 1,714 & 0,174 \\
\hline 3. & Modal kurang & 0,063 & 1,714 & 0,107 \\
\hline 4. & $\begin{array}{l}\text { Produksi dilakukan } \\
\text { belum sesuai } \\
\text { anjuran CPIB }\end{array}$ & 0,094 & 1,571 & 0,147 \\
\hline 5. & Kurang inovasi & 0,039 & 1,143 & 0,045 \\
\hline & Jumlah & 1,000 & & 2,669 \\
\hline
\end{tabular}

Kekuatan dan kelemahan pembenih ikan lele di Desa Babakan digambarkan pada Tabel 6 . Kekuatan utama usaha pembenihan adalah faktor 
kekuatan yang memiliki nilai skor terbobot terbesar, yakni faktor air tersedia sepanjang tahun. Dengan nilai skor terbobot terbesar yakni 0,522 . Faktor air tersedia sepanjang tahun menjadi kekuatan utama bagi pembenih ikan lele di Desa Babakan karena jika pembenih memproduksi benih ikan lele dengan ketersediaan air yang baik maka pembenih akan merasa puas terhadap produksi benih ikan lele yang diperoleh, sehingga pembenih akan memperoleh peningkatan pendapatan sekaligus dapat memenuhi permintaan yang tinggi. Hal ini merupakan peluang yang mungkin dapat ditangkap oleh pembenih untuk mengembangkan usahanya.

Kelemahan usaha pembenihan di Desa Babakan adalah faktor kelemahan yang memiliki nilai skor terbobot terendah, yakni kurang inovasi dengan nilai skor terbobot 0,045 . Padahal inovasi usaha merupakan salah satu faktor penting untuk mengembangkan usaha pembenihan ikan lele lebih baik yang dampaknya akan meningkatkan volume produksi benih ikan lele. Kurangnya inovasi dikarenakan pembenih lebih fokus terhadap teknik yang sudah berlangsung selama bertahun-tahun dan kurangnya pemahaman terhadap inovasi usaha, sehingga inovasi kurang menjadi perhatian pembenih. Secara keseluruhan, total skor terbobot dari matrik IFE adalah 2,669, yang berarti kondisi internal lebih besar dari rataan $(2,5)$ di mana posisi usaha pembenihan ikan lele di Desa Babakan adalah kuat secara internal.

\section{Analisis Matriks EFE}

Matriks EFE digunakan untuk mengetahui faktor-faktor eksternal usaha pembenihan ikan lele berkaitan dengan ancaman dan peluang yang dianggap penting. Setelah diperoleh faktor-faktor strategi eksternal usaha pembenihan yang meliputi peluang dan ancaman, tahap selanjutnya seperti tahapan dalam analisis IFE. Setelah itu dicari nilai skor terbobot untuk masing-masing faktor peluang dan ancaman. Tabel 7 merupakan hasil analisis dari matriks EFE pada usaha pembenihan ikan lele di Desa Babakan.

Faktor-faktor eksternal yang berpengaruh terhadap usaha pembenihan ditunjukkan pada Tabel 7. Peluang utama bagi pembenih ikan lele di Desa Babakan adalah permintaan benih tinggi dengan nilai skor 0,458. Desa Babakan memiliki wilayah yang cukup luas, sehingga banyak penduduknya yang bermata pencaharian sebagai pembenih ikan yang setiap kali musim panen para pembenih tersebut menjual benih secara langsung. Selain itu pembenih memiliki mitra kerjasama yang baik dengan beberapa tengkulak benih, sehingga dalam keadaan sulit untuk mendapatkan pasokan benih, pembenih masih memperoleh permintaan dari para tengkulak tersebut. Hal ini merupakan peluang yang dapat menjadi pendukung bagi pembenih untuk mengembangkan usahanya.

Ancaman utama bagi pembenih, yakni cuaca dengan hujan terus menerus dengan nilai skor terbobot 0,274 . Hal ini merupakan ancaman utama bagi pembenih, karena jika ancaman cuaca tidak dapat di atasi, hasil produksi akan menurun. Oleh karena itu, pembenih harus dapat mengatur padat tebar benih, adanya pergantian air dan penggunaan terpal. Secara keseluruhan, total skor terbobot dari matrik EFE 2,489, berarti kondisi eksternal lebih kecil dari rataan $(2,5)$ di mana posisi usaha pembenihan ikan lele di Desa Babakan, Kecamatan Ciseeng adalah kurang kuat secara eksternal.

Tabel 7. Matriks EFE gabungan usaha pembenihan ikan Lele di Desa Babakan, Kecamatan Ciseeng, Kabupaten Bogor

\begin{tabular}{|c|c|c|c|c|}
\hline \multirow{2}{*}{\multicolumn{2}{|c|}{ Faktor Eksternal }} & Bobot & Rating & $\begin{array}{c}\text { Skor } \\
\text { Terbobot }\end{array}$ \\
\hline & & (a) & (b) & $(\mathrm{axb})$ \\
\hline \multicolumn{5}{|c|}{ Peluang: } \\
\hline 1. & Pasar pasti/tersedia & 0,098 & 3,429 & 0,337 \\
\hline 2. & $\begin{array}{l}\text { Permintaan benih } \\
\text { tinggi }\end{array}$ & 0,139 & 3,286 & 0,458 \\
\hline 3. & $\begin{array}{l}\text { Tenaga penyuluh } \\
\text { perikanan ada }\end{array}$ & 0,107 & 3,143 & 0,335 \\
\hline 4. & Investor & 0,041 & 3,571 & 0,146 \\
\hline 5. & $\begin{array}{l}\text { Merupakan kawasan } \\
\text { minapolitan }\end{array}$ & 0,082 & 3,714 & 0,304 \\
\hline \multicolumn{5}{|c|}{ Ancaman: } \\
\hline 1. & $\begin{array}{l}\text { Saingan usaha } \\
\text { pembenihan dari luar } \\
\text { daerah }\end{array}$ & 0,074 & 1,714 & 0,126 \\
\hline 2. & $\begin{array}{l}\text { Hama (sidat, kodok, } \\
\text { ucrit) }\end{array}$ & 0,090 & 2,000 & 0,180 \\
\hline 3. & $\begin{array}{l}\text { Penyakit (ikan } \\
\text { kembung) sulit } \\
\text { diobati }\end{array}$ & 0,107 & 2,000 & 0,213 \\
\hline 4. & $\begin{array}{l}\text { Cuaca (hujan terus } \\
\text { menerus) }\end{array}$ & 0,148 & 1,857 & 0,274 \\
\hline 5. & $\begin{array}{l}\text { Harga pakan naik } \\
\text { terus }\end{array}$ & 0,115 & 1,000 & 0,115 \\
\hline & Jumlah & 1,000 & & 2,489 \\
\hline
\end{tabular}

\section{Analisis Matriks IE}

Setelah diperoleh total skor dari matriks IFE gabungan 2,669 dan nilai skor dari matriks EFE gabungan 2,489, hasil skor tersebut dapat 
menunjukkan posisi pembenih melalui matriks IE, yaitu pada Sel V. Adapun hasil analisis matriks IE untuk usaha pembenihan ikan lele di Desa Babakan ditunjukkan pada Gambar 1.

Gambar tersebut menunjukkan bahwa posisi usaha pembenihan ikan lele di Desa Babakan berada pada Sel V. Seluruh pembenih memiliki kemampuan internal dan eksternal rataan. Pembenih yang masuk kedalam sel ini dalam kondisi bertahan dan berkembang sebaiknya dikelola dengan strategi bertahan dan pelihara serta strategi penetrasi pasar dan pengembangan produk.

\section{Analisis Matriks SWOT}

Matriks SWOT menganalisis kekuatan, kelemahan, peluang dan ancaman untuk menghasilkan alternatif strategi yang akan dijalankan oleh usaha pembenihan ikan lele. Analisis SWOT merupakan perumusan strategi konvensional yang mendasari terbentuknya strategi-strategi yang dapat disesuaikan dengan posisi usaha pembenihan ikan lele. Berdasarkan analisis matriks IE usaha pembenihan ikan lele di Desa Babakan pada posisi bertahan dan berkembang. Strategi yang cocok diterapkan untuk mengembangkan usaha ditampilkan pada Gambar 2.

Selain pendekatan kualitatif matriks SWOT, pada penelitian ini dilakukan juga pendekatan kuantitatif matriks SWOT. Setelah diperoleh koordinat $(\mathrm{X}, \mathrm{Y})$ dari matriks SWOT gabungan $(1,347 ; 0,672)$, hasil koordinat tersebut dapat menunjukan posisi usaha pembenihan ikan lele di Desa Babakan melalui matriks SWOT, yaitu pada Kuadran I. Hasil analisis matriks SWOT untuk usaha pembenihan ikan lele di Desa Babakan ditunjukan pada Gambar 3. Gambar tersebut menunjukan bahwa posisi usaha pembenihan ikan lele di Desa Babakan berada pada Kuadran I $(100 \%)$, maka usaha pembenihan lele merupakan sebuah usaha yang kuat dan berpeluang.

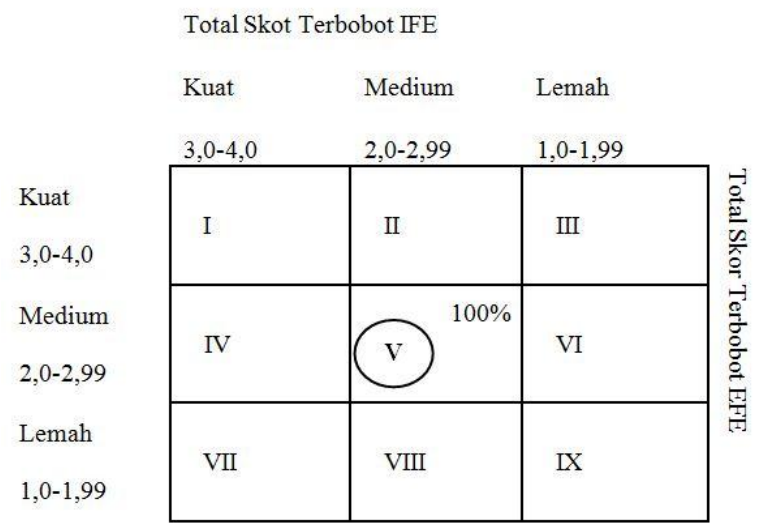

Gambar 1. Analisis Matriks IE usaha pembenihan ikan lele di Desa Babakan, Kecamatan Ciseeng, Kabupaten Bogor

\begin{tabular}{|c|c|c|}
\hline Faktor internal & $\begin{array}{l}\text { Kekuatan (Strengths) } \\
\text { 1. Air tersedia sepanjang tahun } \\
\text { 2. Tenaga kerja tersedia } \\
\text { 3. Lahan untuk pengembangan } \\
\text { tersedia } \\
\text { 4. Pakan alami untuk induk tersedia } \\
\text { 5. Pakan alami benih tersedia (cacing } \\
\text { sutra+kutu air) }\end{array}$ & $\begin{array}{l}\text { Kelemahan (Weaknesses) } \\
\text { 1. Harga dibanding benih dari luar } \\
\text { lebih tinggi } \\
\text { 2. Manajamen usaha tidak tertata } \\
\text { 3. Modal kurang } \\
\text { 4. Produksi dilakukan belum sesuai } \\
\text { anjuran CPIB } \\
\text { 5. Kurang inovasi }\end{array}$ \\
\hline $\begin{array}{l}\text { Peluang (Opportunities) } \\
\text { 1. Pasar pasti/tersedia } \\
\text { 2. Permintaan benih tinggi } \\
\text { 3. Tenaga penyuluh perikanan ada } \\
\text { 4. Investor } \\
\text { 5. Merupakan kawasan minapolitan }\end{array}$ & $\begin{array}{l}\text { Strategi S-O } \\
\text { 1. Produksi benih dapat dilakukan } \\
\text { sepanjang tahun }(\mathrm{S} 1, \mathrm{O} 1, \mathrm{O} 2) \\
\text { 2. Peningkatan produktivitas lahan } \\
\text { (S2, S3, O3, O4, O5) }\end{array}$ & $\begin{array}{l}\text { Strategi W-O } \\
\text { Penerapan CPIB meningkatkan } \\
\text { produktivitas dan kualitas benih } \\
(\mathrm{W} 4, \mathrm{O} 4, \mathrm{O} 2, \mathrm{O} 1, \mathrm{O} 5)\end{array}$ \\
\hline $\begin{array}{l}\text { Ancaman (Threats) } \\
\text { 1. Saingan usaha pembenihan dari } \\
\text { luar daerah } \\
\text { 2. Hama (sidat, kodok, ucrit) } \\
\text { 3. Penyakit (ikan kembung) sulit } \\
\quad \text { diobati } \\
\text { 4. Cuaca (hujan terus menerus) } \\
\text { 5. Harga pakan naik terus } \\
\end{array}$ & $\begin{array}{l}\text { Strategi S-T } \\
\text { 1. Mengantisipasi kendala cuaca dan } \\
\text { pengelolaan mutu air (S1, S2, T2, } \\
\mathrm{T} 3, \mathrm{~T} 4) \\
\text { 2. Menekan biaya pakan buatan } \\
\text { dengan mengoptimalkan pakan } \\
\text { alami (S4, S5, T5) }\end{array}$ & $\begin{array}{l}\text { Strategi W-T } \\
\text { 1. Menekan harga jual strategi } \\
\text { dengan mengatasi persaingan } \\
\text { usaha (W1, T1) } \\
\text { 2. Menerapkan CPIB untuk meng- } \\
\text { atasi persaingan usaha, mengen- } \\
\text { dalikan hama dan penyakit } \\
\text { (W4, W2, T1, T2, T3, T4) }\end{array}$ \\
\hline
\end{tabular}

Gambar 2. Analisis SWOT 
Rekomendasi strategi yang diberikan adalah Progresif, artinya usaha ini dalam kondisi prima dan mantap sehingga sangat dimungkinkan untuk terus melakukan ekspansi, memperbesar pertumbuhan dan meraih kemajuan secara maksimal. Oleh karena itu, pembenih disarankan untuk mengembangkan strategi taktisnya.

\section{Analisis Matriks QSPM}

Setelah melakukan tahapan pengambilan data melalui matriks IFE dan EFE, serta tahap analisis dengan matriks IE dan SWOT, maka tahap selanjutnya pengambilan keputusan dengan QSPM. Teknik ini secara obyektif mengindikasikan alternatif strategi yang terbaik. QSPM menggunakan input dari tahap pertama dan pencocokan dari tahap kedua untuk menentukan secara obyektif diantara alternatif strategi.

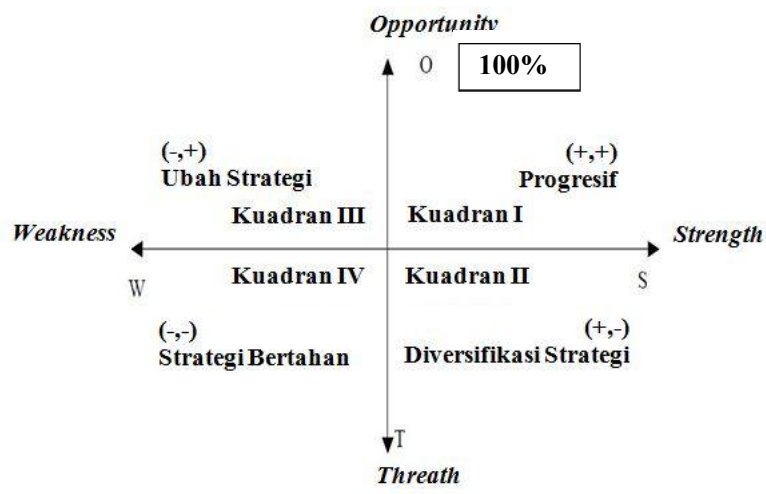

Gambar 3. Diagram SWOT usaha pembenihan ikan lele di Desa Babakan, Kecamatan Ciseeng, Kabupaten Bogor

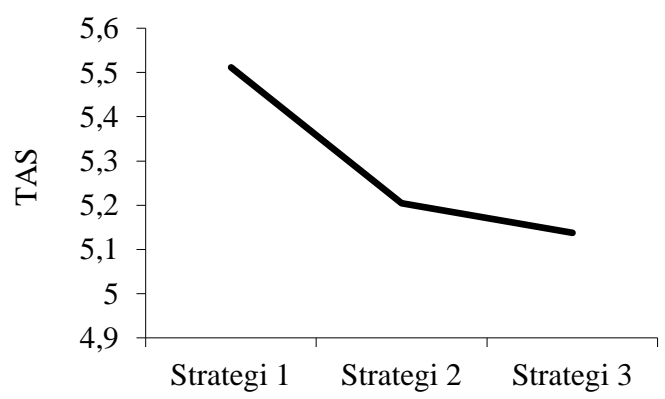

Gambar 4. Grafik analisis QSPM usaha pembenihan ikan lele di Desa Babakan, Kecamatan Ciseeng, Kabupaten Bogor

Dalam membangun QSPM, dibuat daftar kekuatan, kelemahan, ancaman dan peluang serta nilai bobot rataan sesuai matrik IFE dan EFE. Kemudian dari masing-masing faktor ini dicari Attractiveness Score (AS). Nilai AS menunjukkan daya tarik masing-masing strategi terhadap faktor kunci internal dan eksternal usaha pembenihan. Nilai AS diperoleh melalui kuesioner yang ditunjukkan kepada responden, yakni pemilik usaha pembenihan ikan lele di Desa Babakan.

Nilai AS dari masing-masing responden tersebut kemudian dikalikan dengan nilai bobot skor rataan dari masing-masing faktor, sehingga diperoleh nilai TAS (Total Attractiveness Score). Beberapa alternatif strategi yang dianalisis dengan menggunakan QSPM adalah:

1. Penerapan CPIB meningkatkan produktivitas dan mutu benih.

2. Produksi benih dapat dilakukan sepanjang tahun.

3. Mengantisipasi kendala cuaca dan pengelolaan kualitas air.

4. Berdasarkan hasil perhitungan QSPM, diperoleh urutan dari nilai TAS paling tinggi sampai paling rendah. Dari urutan tersebut dapat dihasilkan strategi-strategi prioritas yang dapat diimplementasikan oleh usaha pembenihan ikan lele di Desa Babakan berdasarkan keputusan pemilik usaha pembenihan. Hasil analisis QSPM untuk usaha pembenihan ikan lele di Desa Babakan ditunjukan pada Gambar 4. Berdasarkan hasil analisis QSPM, maka diperoleh prioritas alternatif pada Tabel 8 .

Dalam jangka waktu 3 tahun, implikasi pertama yang dapat dilakukan oleh pembenih ikan lele di Desa Babakan secara manajerial, pembenih dapat melakukan pengembangan usaha. Pengembangan tersebut bisa dicapai dengan mengikuti program pemerintah yaitu menerapkan CPIB, agar semua aspek dapat dikelola dengan baik sehingga tujuan dari program pemerintah tercapai seperti produktivitas usaha meningkat, kualitas benih terjamin dan memaksimalkan potensi yang ada.

Implikasi kedua secara operasional, untuk memaksimalkan usaha pembenihan perlu adanya peningkatkan produktivitas lahan sehingga produksi benih dapat dilakukan sepanjang tahun. Selain itu, jika peningkatan produksi benih dilakukan sepanjang tahun maka kendala kekurangan benih akan dapat ditekan.

Implikasi ketiga secara operasional, bila pembenih mampu mengantisipasi kendala cuaca dan pengelolaan kualitas air akan meningkatkan survival rate benih ikan lele serta dapat menekan biaya pakan buatan. Dengan demikian, pembenih dapat menekan biaya operasional pada usaha pembenihan lele. 
Tabel 8. Alternatif strategi usaha pembenihan ikan lele di Desa Babakan, Kecamatan Ciseeng, Kabupaten Bogor

\begin{tabular}{|c|c|c|c|}
\hline Aspek & Alternatif Strategi & $\begin{array}{l}\text { Total Nilai Daya } \\
\text { Tarik (skor) }\end{array}$ & $\begin{array}{r}\text { Urutan } \\
\text { Prioritas }\end{array}$ \\
\hline Manajemen & $\begin{array}{l}\text { b. Penerapan CPIB meningkatkan produktivitas } \\
\text { dan mutu benih }\end{array}$ & 5,201 & 1 \\
\hline Teknis & $\begin{array}{l}\text { a. Produksi benih dapat dilakukan sepanjang } \\
\text { tahun } \\
\text { b. Mengantisipasi kendala cuaca dan } \\
\text { pengelolaan kualitas air }\end{array}$ & $\begin{array}{l}4,729 \\
4,698\end{array}$ & $\begin{array}{l}2 \\
3\end{array}$ \\
\hline
\end{tabular}

Implikasi keempat secara operasional, pembenih ikan lele agar mampu menekan harga jual dalam mengatasi persaingan usaha dengan pembenih luar yang menjual benih diwilayahnya serta penerapan CPIB dalam mengatasi kendala hama dan penyakit, akan meningkatkan penjualan dari hasil pembenihannya. Menurut Kusumawardani, Gumili, dan Rostini (2012), persaingan usaha perlu menggunakan sumber daya secara efisien, artinya seluruh sumber-sumber daya yang tersedia sepenuhnya digunakan.

Hasil penelitian di Desa Babakan Kecamatan Ciseeng dapat di implementasikan di wilayah lain. Syaratnya yaitu adanya upaya dari pembenih ikan lele untuk merubah pola usaha, sesuai dengan program pemerintah untuk menerapkan CPIB, sehingga kegiatan usaha pembenihannya dilakukan secara baik dan benar.

\section{KESIMPULAN}

Kelayakan non finansial dari 7 pembenih ikan lele di Desa Babakan menunjukkan bahwa masih lemah pada seluruh aspek non finansial (hukum, pemasaran, teknis, manajemen, sosial ekonomi dan lingkungan). Kelayakan finansial dengan kriteria kelayakan dan asumsi yang telah ditentukan menunjukkan bahwa usaha pembenihan ikan lele dari 7 pembenih di Desa Babakan dinyatakan layak.

Berdasarkan analisis matriks IE, strategi yang dapat diterapkan adalah penetrasi pasar dan pengembangan produk. Berdasarkan analisis SWOT, strategi yang perlu dilakukan oleh usaha pembenihan ikan lele di Desa Babakan adalah Progresif, artinya usaha ini dalam kondisi prima dan mantap sehingga sangat dimungkinkan untuk terus melakukan ekspansi, memperbesar pertumbuhan dan meraih kemajuan secara maksimal. Oleh karena itu, pembenih disarankan untuk mengembangkan strategi taktisnya. Sedangkan hasil analisis matriks QSPM, didapatkan alternatif strategi pengembangan usaha terbaik, yaitu penerapan CPIB yang dapat meningkatkan produktivitas dan mutu benih.

\section{DAFTAR PUSTAKA}

Adelina. 2011. Faktor-faktor Yang Memengaruhi Minat Berwirausaha Budidaya Lele Sangkuriang. Jurnal Ekonomi dan Manajemen. Fakultas Ekonomi Jurusan Manajemen Universitas Gunadarma.

Ditjen P2HP. 2010. Direktorat Jenderal Pengolahan dan Pemasaran Hasil Perikanan dalam angka. Direktorat Jenderal Pengolahan dan Pemasaran Hasil Perikanan. Yogya Konsumen Lele Tertinggi. [internet]. [diacu 2013 Agustus 30]. Tersedia dari: http://www.wpi.kkp.go.id/2010.

Ferazuma, H., Marliyati, S. A. dan Amalia, L. 2011. Substitusi Tepung Kepala Ikan Lele Dumbo (Clarias gariepinus Sp) untuk Meningkatkan Kandungan Kalsium Crackers. Jurnal Gizi dan Pangan, 6(1): 18-27.

Jaja, A. Suryani dan K. Sumantadinata. 2013. Usaha Pembesaran dan Pemasaran Ikan Lele serta Strategi Pengembanganya di UD Sumber Rezeki Parung, Jawa Barat. Jurnal Manajemen IKM, 8 (1): 45-56.

KKP. 2011. Kementerian Kelautan dan Perikanan Republik Indonesia dalam angka. Kementerian Kelautan dan Perikanan Republik Indonesia. Penerimaan Penyuluh Perikanan Tenaga Kontrak (PPTK) Kementerian Kelautan dan Perikanan. [internet]. [diacu 2012 Agustus 30]. Tersedia dari:

http://www.kkp.go.id/index.php/arsip/c/67

57/Penerimaan-Penyuluh-Perikanan-

Tenaga-Kontrak-PPTK-Kementerian-

Kelautan-dan-Perikanan/

KKP. 2012. Kementerian Kelautan dan Perikanan Republik Indonesia dalam angka. Kementerian Kelautan dan Perikanan Republik Indonesia. Bisnis Ikan Lele Menggiurkan. 
[internet]. [diacu 2013 Maret 31]. Tersedia dari: http://www.kkp.go.id/index.php/arsip/c/6990/Bisnis-Ikan-Lele-Menggiurkan 26/01/2012.

Kusumawardani, IS., I. Gumila dan I. Rostini. 2012. Analisis Surplus Konsumen dan Surplus Produsen Ikan Segar di Kota Bandung. Jurnal Perikanan dan Kelautan, 3 (4): 141-150.

Mervina, Kusharto, C. M. dan Marliyati, S.A. 2012. Formulasi Biskuit dengan Substitusi Tepung Ikan Lele Dumbo (Clarias gariepinus) dan Isolat Protein Kedelai (Glycine max) sebagai Makanan Potensial Untuk Anak Balita Gizi Kurang. Jurnal Teknologi dan Industri Pangan, 23 (1): 9-16.

Pemerintah Kabupaten Bogor. Dinas Peternakan dan Perikanan. 2010. Buku Data Perikanan Tahun 2010, Cibinong.
Pemerintah Kabupaten Bogor. Dinas Peternakan dan Perikanan. 2012. Buku Data Perikanan Tahun 2012, Cibinong.

Sukardono, E., M. Sarma dan K. Sumantadi-nata. 2013. Strategi Pemasaran Restoran Pecel Lele Lela Cabang Pinangranti, Jakarta Timur. Manajemen IKM, 8 (2): 170-180.

Wibowo BP. 2011. Bisnis Benih Lele Untung 200\%. PT Penebar Swadaya, Jakarta.

Yulinda, E. 2012. Analisi Finansial Usaha Pembenihan Ikan Lele Dumbo (Clarias Gariepinus) di Kelurahan Lembah Sari Kecamatan Rumbai Pesisir Kota Pekanbaru Provinsi Riau. Jurnal Perikanan dan Kelautan 17 (1): 38-55. 